\title{
Cultural Identity Post-Conflict: Crisis of Madurese Culture Identity in Sampit Central Borneo after 2001 Ethnic Conflict
}

\author{
Yesi Yonefendi*; Pawito Pawito; Mahendra Wijaya \\ Department of Communication Science, Universitas Sebelas Maret, Indonesia \\ Email: yon.efendi05@student.uns.ac.id
}

http://dx.doi.org/10.18415/ijmmu.v5i5.444

\begin{abstract}
The research attempts to examine the crisis of Madurese cultural identity exposure in intercultural communication in Sampit (Central Borneo Province) after the 2001 ethnic conflict which involved two major ethnic groups i.e the Dayak ethnic (native community) and Madurese ethnic (migrant community). Using base descriptive qualitative approach by interviewing a numerous Madurese people living in Sampit and using literature review. The research reveals that affected the formation of cultural identity among the residents of Sampit of Madurese descent. This Cultural identity experienced a crisis and change, because not in accordance with the value of local culture. In other hand the research found that cultural identities of Madurese are strengthened. It arises because of conformity and mutual support with local cultural values. Understanding to intercultural communication is very important to create acculturation with local culture to avoid problems due to cultural differences, especially for newcomers from the Madura Island.
\end{abstract}

Keywords: Culture Identity; Ethnict Conflict; Identity Crisis; Communication

\section{Introduction}

When hearing the term of culture, will lead to the existence of ethnic or tribal groups, with various customs and traditions. This is natural, because from there cultural is formed. The cultural form as ideas, values, norms, regulations, action, activities, patterned of human's life in a society or objects from human work from there become available (Alfan., 2013). The form of culture is strongly influenced by cultural subjects, namely humans themselves. The more members of the group who maintain that culture, the cultural identity will be strengthened and vice versa, culture will disappear when people who neglected (Magetsari., 2016). Finally, humans themselves have the role to bring the culture will back and forth.

Humans in fulfilling their life necessities, sometimes must to move to another area. This movement can occur within the local, regional and global scale. The goal is to get better welfare certainly. This move will bring together the culture by immigrants to the local culture, and cultural acculturation will occur between them. Therefore, often in one area displays of cultural performances from other regions. 
The same happened in the city of Sampit, as one of the cities in the Central Borneo Province of. Having a port that has direct access to other regions or islands, as well as investment opportunities and conveniences, is a magnet for this city (Anwar., 2003). This makes Sampit city residents very diverse, besides the indigenous Dayak tribe, there are other tribes and groups such as Banjar, Javanese, Madurese, Bugis, Balinese, Batak, Chinese and other tribes (Badan Pusat Statistik., 2011). The Madurese tribe as one of the immigrant tribes became important in the history of this city. The existence of Madurese tribes is very phenomenal, because it relates to horizontal conflict events in 2001. This conflict involving ethnic Dayaks and Madurese had seized the world's attention and became a dark history for humanitarian events in Indonesia (Anwar., 2003). Whereas before, many of them had lived and lived for generations in Sampit, even those who were married to indigenous people. They also play a role in building and advancing this city, for example in education such as establishing Islamic boarding schools and madrasah (Mualim. M, personal communication, May 5., 2018).

According Anwar (2004), the Madurese tribe actually had existed for a long time in Sampit, although there were no official documents, but some said that they had existed since the Japanese occupation in 1942 to 1943 . Then there was a large-scale entry when developed Trans-Kalimantan road with many employs as rude labor. The road connects the city of Palangkaraya with Sampit along $217 \mathrm{~km}$ (Abduh., 2003). The increasing number of Madurese who enter, causes increasingly rapid population growth, especially Sampit. With the inherent stereotypes of Madurese who are hardworking and picky in their work, finally their various lines of life are mastered such as port workers, pedicab drivers, traders in the market, transportation city and so on (Abduh., 2003).

With the occurrence of inter-ethnic conflicts where previously they were evacuated entirely. Their peace efforts, and finally they allowed to return live in Sampit. What about the existence of the Madurese cultural identity at this time? And is there encounter of cultural identity crisis? The research will reveal the problem by using the postpositivism research approach with descriptive qualitative methods. Data collection is done by interviews, documentation and observation.

\section{Methodology}

This research is a field research, where it is carried out in particular area by directly seeing what happens in the social community. The study using qualitative descriptive approach with a case study method. This approach was taken because this study intends to overview and explain about the social symptoms that exist in research location. Furthermore, to collect data is done with observation techniques and in-depth interviews. Interviews were carried out on informants who came from among the Madurese figures who experienced the conflict. While observations are made toward the culture that shown their community. Furthermore, to support the data obtained, a literature review from previous studies was carried out with the same theme. The research continues with validation testing using source or data triangulation techniques. This validation does not aim to determine which data is correct and wrong. However, it is more directed to show empirical evidence to provide an understanding of the cases observed from various perspectives. Finally, a more comprehensive conclusion can be obtained

\section{Related Works}

Humans have advantages compared to other (animals and plants), that have reason and mind or commonly referred to as thoughts and feelings (Widagdo., 2015). With human reason can determine how to live and fulfill the demands life. But humans cannot fulfill all their needs alone and need the presence of others. As social beings, humans interact, with fellow humans or with other objects around them. The 
effects of these interactions will create groups among people. From the group they create joint activities, and bring up agreed habits and eventually become a culture.

Culture arises when humans as individuals have fundamental things, namely inner values, such as truth, virtue and beauty. That value will be further concretized in the form of skills, dexterity, justice, generosity and other functions that make up human nature based on his experience and education (Bakker., 1984). On the other hand, when humans interact in a social environment by bringing and possessing these values, culture will be created. So that culture is a way of life that develops and is shared by a group of people and passed down from generation to generation. Culture as a result of a social agreement so that it is used as a joint rule in acting for its members. Cultural sustainability will be passed on to the next generation through the learning process carried out from previous generations, where this process will be influenced by the experience of each and the circumstances in the environment faced (Alfan., 2013). The form of culture according to Koentjoroningrat can be translated into three, namely 1) ideas, ideas, values, norms, regulations and so on; 2) activity and patterned actions of humans in a society; 3) objects from human works (Alfan., 2013).

When the form of culture becomes a symbol and has meaning, or can be interpreted by humans then occur of communication process (Cangara., 2012). EM. Griffin said that communication is the relational process of creating and interpreting messages that elite response (Griffin., 2012). Departing from this understanding can be explained when interpret of the symbols on culture, then an identity is formed. So. Martin and Nakayama said that communication is a bridge between culture and identity. Identity in the concept of identity refers to who we and others think about us (Martin \& Nakayama., 2010). When it is returned to the cultural concept above, it can be said that cultural identity refers to a sense of belonging or as part of a particular ethnic group or culture. Cultural identity is formed in the process that results from membership in a particular culture, and this involves learning about the acceptance of tradition, inheritance, language, religion, ancestry, aesthetics, mindset, and socio-cultural structure (Lustig and Koester., 2010).

As time goes, identity will be formed following social conditions, this can be eaten up that identity always change. Identity can become stronger, in other hand identity can be weakened or even lost. This occur due to erode by a strong civilization influence or not maintained interface so will be forgotten by people who have it (Magetsari., 2016). This kind of situation can be said as an identity crisis, so culture can also experience a crisis.

The Oxford Dictionary defines crisis into two meanings, first as pathology, which means a point in the development of an illness when important changes occur such as before recovery or death. Both transfertive and figurative meanings, which means a very important stage to determine in the development something; a turning point; or change to decisive towards better or worse conditions (Wahid., 2009). However, the crisis in general will be related to negative understanding, helplessness, damage. If the crisis is linked to culture, the cultural crisis, therefore Huliselan said the cultural crisis is a condition of cultural helplessness as a driving force of progress for its aggots, or in other words a crisis. Culture results in the loss of identity both individuals and cultural support groups (Huliselan., 2003). However, it should be underlined that the cultural crisis with cultural shifts is a different matter in which cultural shift does not cause its supporters to lose their identity and not eliminate the basic values of the culture. Cultural crises can occur because of the coercion of certain communities to follow other cultures, these forms of coercion can lead to social conflicts because there are those who fight but some accept with compulsion to avoid conflict.

\section{Overview of Ethnic Conflict in Sampit}


Various horizontal conflicts experienced by Indonesian after reforms in the late 1990s until the early 2000s is invited the thoughts. Some say that conflicts in the national context are caused by overflowing of confinement during the Orde baru era leadership (Trijono, Dewi \& Qadir., 2004) with monocultural political policies for the reason of national stability and social integrity (Suharno., 2015), at the time the government presses against various issues as tribe, religion, ethnic and groups. Leveraging them can be considered as subversive activities and considered to cause national disintegration (Asgart., 2003). This view was justified by the marked emergence of social conflict that occurred almost simultaneously in various regions. Regardless of the cause, the social conflict should be avoided, because in Indonesia difference is a necessity, which should be a vehicle for the process of social interaction, and managed to produce cooperative and integrative relationships in a pluralistic society (Asgart., 2003).

Inter-ethnic conflict that occurred in Sampit between Dayak tribes as local people and Madurese as migrants did not occur suddenly, there was a series of events that preceded it and had not been resolved completely. Unequivocal law enforcement, partiality towards the resolution of social conflicts until there are indications of bribery, injustice triggers open conflict (Patji., 2003). In addition, this terrible conflict (Asgart., 2003) according to Soemarjan is also an impact of the conflict that occurred in the previous year in West Kalimantan. Conflicts between ethnic Dayaks and Madurese have often occurred, namely in 1969, 1968, and 1986, then in West Kalimantan again in 1999 and in Central Kalimantan in 2001. If the conflict always recurs, there are two of causes, first the resolution of the previous conflict was not complete and not touched the problem from the grassroots, and secondly it could be possible to re-occur the same conflict in another area (Ruslikani., 2001).

The Sampit Conflict resulted very large of impacts, both soul and property. Mentioned by a spokesman for the regional government of Central Borneo Province, the conflict that occurred in two cities namely Sampit and Palangka Raya claimed 357 people were killed, in which 341 people including ethnic Madurese, then 571 houses were burned. Stated from other sources from 18 February to 6 March 2001 which recorded 1192 houses burned, 748 houses destroyed, 16 four wheels, 43 two wheels and 114 vehicles were burned, 371 people died and 270 people were seriously injured. While the number of refugees in Madura Island is as much as 50,000 more (Puslitbang Ministry of Religion., 2003).

Peace over this conflict was pursued by the government. The provincial and district governments make resolutions and bring together conflicting ethnic figures. Although through a long process, finally the agreement was reached by allowing refugees to come back conditionally. Legalized peace agreements in the regulations, require Madurese descendants who want to return must respect and uphold the philosophy of "balum bahadat", which is a belief to uphold order, values or norms, and manners, which are the custom of the local community and hold the philosophy "dimana bumi dipijak disitu langit di junjung", where the earth is stepped on there the sky is upheld (Suharno., 2013; Purwana., 2010; Suharno., 2015). Kotawaringin Timur District Regulation number 5 of 2004 which was promulgated on July 9, 2004, became a tool to reintegrate two conflicting ethnicities. Madurese who had previously been displaced as a whole, are now gradually returning to the Sampit and they can be accepted again coexist although conditionally (Suharno., 2013). It starts from here, finally the new cultures for the Madurese in Sampit.

\section{Result}

Many Madurese have settled in Sampit, even from generation to generation with their ancestors. Many of them have no relatives in their home region, Madura Island. They have become Sampit people, although they are ethnically Madurese. Their presence in Sampit generally begins with invited by family, friends who have previously settled, but sometime they themselves want to go to Sampit because they see other people success first. When they have been living for a long time, then they take care of becoming 
residents of Sampit and continuously. So, until now there are always migrants from the Madura Island. According one of Madurese people, these Madurese migrants sometimes bring unfavorable traits from their origin to Sampit, and eventually can cause problems. In the future they gradually increased the number of Madurese in Sampit more and more, thus their cultures were often shown in various aspects of life.

How Madurese ethnic culture in Sampit before the riots happened? it can be observed in the Sjuhada Abduh research (Abduh., 2003). The results of his research revealed that before the incident in Sampit more than 50\% were Madurese, even there still many who had not reported themselves to the local village goverment. It is not difficult to get them, because they live on the banks of rivers, ports and agricultural areas. Those who are known as hard workers, do not choose jobs and finally they dominate various fields of life. Their job as manual labor, agriculture, motorcycle or taxi drivers, pedicab drivers, satay sellers, market traders, oil suppliers, gas stations, contractors, port loading and unloading personnel, even the prostitution business was carried out by Madurese. In the government sector they are not interested, because most of them not know about education, only a few of them are government employee.

The distribution of residences is mostly located in the city center, where many of them live in groups such as in Pelalangan, Baamang, Jl. H. Ikap, Jl. S. Parman, in addition they also live in outside of the city, such as Samuda, Parebok, Kotabesi, Parenggean. Where they live seems they are successful. Their success can be seen from their magnificent houses, on average equipped with satellite dishes.

\section{Cultural Identity Crisis Post-Conflict}

As previously explained, once the riots happened all Madurese descendants were all evacuated out of the area, until peace agreement was reached so that the Madurese could naturally return to the Sampit, with conditionally (Wahid \& Ilyas., 2004). Upon their return gradually or naturally mentioned, then they can coexist and interact with local people in this case the Dayak tribe and with other tribes. As we know that a community will create a culture to show the existence of the community. Discussing about how Madurese show their cultural identity can be seen from the following cultural supporting elements.

First, language. In general, the people of Madurese descent in Sampit use Madura language everyday, as mother language at home. In addition, they use it when communicating with fellow Madurese ethnicities outside their families, who are still in the Madura environment. Whereas when in a public place, they use Sampit language, although with the same ethnic Madurese, such as in markets, shopping centers, recreation areas. However, they sometimes still use Madurese if there are special things discussed. Meanwhile, there are some Madura families who do not use Madura to communicate in their families, they use sampit language, and this is due to their previous habits. The level of education, the scope of work and the form of their association with various other ethnicities also caused it. In the case of language, it should be underlined, although they use outside their language, will be different in terms of the dialect. What is difficult to distinguish is language used by most of Madurese first generation or who born after the riots, they have mingled with local people so that they use Sampit more.

In principle, by language observation, it is very easy to know about Madurese culture identity, it is still used primarily for ordinary citizens and immigrant madura, but among educated, wide-ranging and teenagers prefer to use the Sampit language. The environment also affects them, if around the place of residence and association are fellow Madurese, the language is still very thick. However, if they meet and communicate with other tribes they use the Sampit language, in contrast before the riots, it is opposite, to able communicate with the social environment, other tribes must learn and be able to speak Madura. 
Second, clothes. In the case of clothing in general the same as most, but there are some different from the dress character for the residents Madurese. For citizens who are elderly, it is very easy to recognize as Madurese, as seen from the dress model, which is wearing sarong, and wearing a cap, they use it on daily, sometimes when they relax at home, go to certain events and it has become a habit and difficult to change, but that doesn't happen to youth and teenagers.

Third, art performances. One form of culture can be seen in activities with form of traditional art performances and symbols. In this case Madurese certainly have art that is brought from their home region Madura Island, and passed on to their generation in Sampit. Based on the field findings several traditional arts owned by the Madurese in Sampit are currently experiencing changes or even disappear namely Sandur and Ronggeng. Riots have become the starting point for the phenomenon of change. Whereas before the riots it is very strong attached with existence of Madurese in Sampit, the meaning is if the performance was held it was clear those carried out by Madurese citizens.

Although there are no prohibition rules, from the post-riots until now this art has never been shown again. Like the narrative informant of that ronggeng arts including sandur, was actually revived by immigrants from Madura, who had habits there. While the people who had been handed down from here, average had mingled to become sampit people. The newcomers later supported by long-standing figures here, and finally the minority flourished and became a tradition here. For the performance of the show, they form a group and held arisan. So, it will be held in rotation who gets the turn. So, the holding of ronggeng or sandur is not necessarily that they have a function like a marriage, but if get their turn, it will be held and could be that there is a show every month.

In traditional art performances will followed by alcohol and gambling. This performance is also prone to violence, considering in general those who come to the show, carry their unique weapons "celurit". This kind of culture often provokes problems and fights often occur between them during the event. Although not all Madurese like this art, but its existence is shows Madurese cultural identity. Looking at the value of traditional art is good, because it shows the richness of the traditions, but the culture that accompanies it makes the values contained in the tradition become corrupt, so that they seem identical with violence and disobedience. After the riots the show disappeared, until now there were no more performances. However, what is now reappeared and become the cultural identity of Madurese citizens is the concept of arisan that is applied which aims to help other people to make his event.

Fourth, behavior. This culture experienced many changes according to the informants who were met and also the Madurese said the change in temperament of most Madurese was far better after the riots. In the past he himself before the riot was afraid of the Madurese because of his temper and behavior, they invited Carok and patted his chest a little. What was conveyed by the informant was also in accordance with Abduh's research findings which stated that the living culture of Madurese people in Sampit still carried a lot of culture from its origin. Just because trivial problems have carok, when in fact if according to the original tradition carok for self-esteem, is done if there is harassment against women and her husband feels insulted. In Sampit it is not so just because nudging at a gambling place can lead to murder. Before the riots the news of the killings happened very often, both with fellow Madurese and with other tribes. Eventually the riots became a turning point for various changes in cultures owned by Madurese in Sampit.

Fifth, the use of regional symbols. Celurit is a weapon that very identical with Madurese tribe. Before the riots often found, many Madurese people brought this weapon when they left their house, especially when attending Ronggeng, now it was not seen brought out the house by Madurese people. The tool is now no longer a trend, if it is associated with the riots they have pressure and trauma, so they avoid things that can arouse suspicion. 
Sixth, religious activities. Madurese tribe residents are actually very thick with religious nuances, namely Islam, a culture that can become an identity for the existence of the Madurese community is "mauludan", and this event was held to commemorate the birth of the Prophet Muhammad. In general, every Muslim community in Sampit also commemorates, usually they carry out in mosques with together. However, different things done by the Madurese community they also held events in their homes by inviting right and left neighbors for salvation. This event has become a necessity for them. This event is more directed to tradition, no an actualization of religious obedience, this can be illustrated, even though someone is not religious in their daily lives but they still hold this.

\section{Discussion}

Some of the explanation above are cultural images that are identical to the Madurese tribe in Sampit. Then what kind of identity does the crisis experience or shift. As stated by Griffin that in the communication of identity communication can be formed when there is communication (Griffin., 2012). That cultural identity is formed based on interactions and negotiations between oneself and group affiliations (Chen \& Zhang., 2010). This illustrates that when a culture that is both in the form of norms, activities and objects possessed by the Madurese tribe in Sampit, is not communicated to others, then identity will weaken and will disappear. Communicating here can be interpreted as carrying out the communication process, namely the meaning of the symbol used, the interpretation carried out, the negotiated transactions, and the effect of the message conveyed when the transaction occurs is a form of communication and fulfilling the elements of communication, namely the source, message, media, recipient, influence, feedback and environment (Cangara., 2012). So, it can be said that to interpret the symbol, culture must be displayed so other people will be able to interpret that symbol. If the cultural form is not shown, then the cultural identity will automatically disappear. In this case, the riot caused the culture to be banned in an unwritten manner. So, it was not displayed until now, because it could raise problems, could disrupt security and peace.

As explained by average informant that the experience of riots is extraordinary, many hopes that the event is first and last. Therefore, for newcomers who need to be re-socialized about how to live in the land of people, how to apply use philosopy where the earth is stepped on there the sky is upheld. Some suggest to all Madurese migrants need to be recorded and briefed before they live in Sampit. The goal is migrants can adaptation and not clash with local culture.

\section{Conclusion and Suggestion}

Based on the results has been described previously, some conclusions can be drawn. First, the conflict that occurred between ethnic groups in 2001 affected the formation of cultural identity among the residents of Sampit of Madurese descent. Second, the discovery of cultures that are no longer communicated so they experience an identity crisis. This situation can be seen in the performance art as sandur and ronggeng, where the cultural values not accordance with the local culture in Sampit and prone to cause problems. They did not to show it, in order to maintain peace and security. In other hand, some culture has undergone a change, it can be seen in the use of the Madurese language, and it is only used among their communities, while in public places they use the Sampit language. The same thing is seen in the use of language by their offspring teenagers who are more open to using Sampit language than their Madura language.

Third, the culture does not experience a crisis, even tends to strengthen changes can be seen in Mauludan culture. This is because the value of the culture does not conflict with the local culture 
community and can synergize and complement each other. The tendency to show identity also seen in arisan culture which continues to develop until now.

The suggestion is trying to put forward and understand intercultural communication especially for newcomers from the Madura Island, to create acculturation with local culture to avoid problems due to cultural differences.

\section{References}

Abduh, S. (2003). Tragedi Berdarah di Kotawaringin Timur Kasus Dayak dan Madura Tahun 1999. Dalam Puslitbang Kehidupan Beragama. Seri II Konflik Sosial Bernuansa Agama di Indonesia. Jakarta: Departemen Agama.

Alfan, M. (2013). Filsafat Kebudayaan. Bandung: Pustaka Setia.

Anwar, W. K. (2003). Merajut Sampit Dalam Prespektif Global. Jakarta: Indomedia.

Asgart, S. M. (2003). Politisasi Sara: Dari Masa Orba Ke Masa Transisi Demokrasi. Jakarta: ISAI.

Badan Pusat Statistik. (2011). Kewarganegaraan, Suku Bangsa, Agama, dan Bahasa Sehari-hari Penduduk Indonesia Hasil Sensus Penduduk 2010. Jakarta: Badan Pusat Statistik.

Cangara, H. (2012). Pengantar Ilmu Komunikas, Edisi Kedua. Jakarta: Raja Grafindo Persada.

Chen, M.G, Zhang, K. (2010). New Media and Cultural Identity in the Global Society. In Rotimi Taiwo (Eds.) Handbook of Research on Discourse Behavior and Digital Communication: Language Structures and Social Interaction. New York: Information Science Reference.

Griffin, Em. (2012). A First Look at Communication Theory, Ed. $8^{\text {th }}$. New York: McGraw-Hill.

Huliselan, M. (2003). Krisis Kebudayaan Konflik dan kekerasan. Dalam Suminar dkk. Integrasi dan Disintegrasi Dalam Prespektif Budaya. Jakarta: Bupara Nugraha.

Lustig, M. W., Koester, J. (2010). Intercultural Competence Interpersonal Communication Across Cultures. Boston: Pearson Education. Inc.

Magetsari, N. (2016). Krisis Identitas. Dalam Sarumpaet, R. K. T. Krisisi Budaya? Oasis Guru Besar Fakultas Ilmu Pengetahuan Budaya. Jakarta: Yayasan Pustaka Obor Indonesia.

Martin, J. N., Nakayama, T. K. (2010). Intercultural Communication In Contexts, Ed. $5^{\text {th }}$. New York: McGraw-Hill.

Patji, A. R. (2003). Tragedi Sampit 2001 dan Imbasnya Ke Palangka Raya Dari Konflik Ke Rekonstruksi. Jurnal Masyarakat dan Budaya, 5(2): 14-34.

Puwana, B. H. S. (2010). Konflik Antar Komunitas Etnis dan Representasi Identitas Etnis di Sampit Kalimantan Tengah. Jantra, 5(10): 883-896.

Ruslikan. (2001). Konflik Dayak-Madura di Kalimantan Tengah: Melacak Akar Masalah dan Tawaran Solusi, Masyarakat, Kebudayaan dan Politik,14(4): 1-12. 
Suharno., Samsuri., Nurhayati., Iffah Nur. (2013). Pengembangan Model Resolusi Konflik Untuk Masyarakat Multikultural (Studi Implementasi Kebijakan Resolusi Konflik Di Sampit, Poso, Dan Ambon). Yogyakarta: Laporan Tahunan Penelitian Hibah Bersaing 2013, LPPM - Lembaga Penelitian Dan Pengabdian Kepada Masyarakat UNY http://eprints.uny.ac.id/id/eprint/22690.

Suharno. (2015). Kebijakan Berbasis Politik Rekognisi dan Resolusi Konflik Etnik. Socia, 12(1): 66-74.

Trijono, L., Dewi, K.S., Qodir, Z. (2004). Memetakan Konflik, Membuka Jalan Indonesia Damai. In Trijono et. Alhamdulillah (Eds). Potret Retak Nusantara Studi Kasus Konflik di Indonesia. Yogyakarta: CSPS Books.

Wahid, A. (2009). Bertahan Ditengah Krisis: Komunitas Tionghoa dan Ekonomi Kota Cirebon Pada Masa Depresi Ekonomi, 1930-1940. Yogyakarta: Ombak.

Wahid, A. Ilyas, M. (2004). Berdamai Dengan Sejarah Panduan Praktis Mengelola Konflik. Yogyakarta: Alinea Press.

Widagdo, D. (2015). Ilmu Budaya Dasar. Jakarta: Bumi Aksara.

\section{Copyrights}

Copyright for this article is retained by the author(s), with first publication rights granted to the journal.

This is an open-access article distributed under the terms and conditions of the Creative Commons Attribution license (http://creativecommons.org/licenses/by/4.0/). 